Kemudi: Jurnal Ilmu Pemerintahan | 193

Volume 03 Nomor 02 Februari 2019

2622-9633 (Online) 2528-5580 (Cetak)

Open Access at: https://ojs.umrah.ac.id/index.php/kemudi

DOI: https://doi.org/10.31629/kemudi.v3i2.856

\title{
PERAN DAN PARTISIPASI PEMUDA DALAM PENGEMBANGAN WISATA DI DESA PONGKAR KABUPATEN KARIMUN
}

\author{
DHANI AKBAR \\ Dosen Hubungan Internasional, Fakultas Ilmu Sosial dan Ilmu Politik \\ Universitas Maritim Raja Ali Haji \\ rittersarmy@gmail.com \\ TEGUH SETIANDIKA IGIASI \\ Dosen Sosiologi, Fakultas Ilmu Sosial dan Ilmu Politik \\ Universitas Maritim Raja Ali Haji \\ minoritas.instruktur@gmail.com
}

\begin{abstract}
The community structure in Pongkar village, Karimun Regency, consists of various cultural backgrounds. However, the existence of the tribal community, which is part of the concept of Remote Indigenous Communities, makes Pongkar Village more attractive in developing local wisdom-based tourism for the local community. Cultural fusion in planning the development of tourism potential in Pongkar Village is needed to accommodate the values of the local people. The method used to obtain data in this study is a qualitative method. Youth participation in tourism-awareness-programs should be encouraged as a lesson for young people to have roles and responsibilities in advancing their villages. This is also being done by the village of Pongkar. The participation of the youth in Pongkar village is quite good, but it would be nice to have more than just a role in participation, that is to take part in developing the village by combining fresher thoughts.
\end{abstract}

\section{Key words: youth, tourism, development, participation}

\begin{abstract}
ABSTRAK
Struktur masyarakat yang berada di Desa Pongkar Kabupaten Karimun terdiri dari beragam latar belakang kebudayaan meskipun masih didominasi oleh Melayu. Namun keberadaan komunitas suku laut yang merupakan bagian dari konsep Komunitas Adat Terpencil dalam Undang-undang, menjadikan wilayah Desa Pongkar menjadi lebih menarik dalam mengembangkan wisata berbasis kearifan lokal masyarakat setempat. Butuh adanya peleburan budaya dalam merencanakan pengembangan potensi ekowisata berbasis kearifan lokal di Desa Pongkar Kabupaten Karimun. Sehingga semua kebudayaan masyarakat di Desa Pongkar terakomodir dan tidak ada nilai-nilai masyarakatnya yang cukup beragam tersebut yang tercederai. Metode yang dipakai untuk mendapat data dalam penelitian ini adalah metode kualitatif maka ada komponen-komponen metode kualitatif yang harus diperhatikan oleh peneliti. Partisipasi pemuda dalam program sadar wisata seharusnya memang digalakkan sebagai sebuah pembelajaran bagi para pemuda bahwa mereka juga punya peran dan tanggung jawab dalam memajukan desanya. Hal ini
\end{abstract}


juga yang sedang dilaksanakan oleh desa Pongkar, yang berada di Kecamatan Tebing, Kabupaten Karimun, Provinsi Kepulauan Riau. Partisipasi para pemuda di desa Pongkar bisa dikatakan cukup baik, namun alangkah baiknya tidak saja berperan dalam partisipasi tapi juga ikut ambil bagian dalam pengembangan desa tersebut karena bisa saja timbul banyak pemikiranpemikiran yang lebih segar.

\section{Kata Kunci: Pemuda, Wisata, Pengembangan, Partisipasi}

\section{Pendahuluan}

Keppres No. 6 tahun 2017 tersebut juga menunjukkan bahwa Provinsi Kepulauan Riau merupakan wilayah yang banyak memililki pulau terdepan Negara Indonesia. Diantaranya seperti Kabupaten Karimun yang berdasarkan Keppres tersebut memiliki Dua (2) buah pulau terluar, yakni Pulau Karimun Kecil di Desa Pongkar serta Pulau Iyu Kecil (Balai Pengelolaan Sumber Daya Pesisir dan Laut).

Potensi wisata yang dimiliki Indonesia khususnya Kabupaten Karimun Kepri sangat besar, keanekaragaman budaya dan keindahan alam di Karimun Kepri sangat berpotensi untuk dikembangkan. Upaya pengembangan desa wisata menjadi suatu alternative dalam upaya peningkatan keterlibatan atau partisipasi masyarakat dalam pengembangan sektor wisata. Dalam pengembangan pariwisata menjadi penting untuk menonjolkan sifat kreatif masyarakat lokal, perlu memberikan stimulan berupa apresiasi cara bagaimana mengemas kegiatan sosial dan budaya menjadi salah satu label produk ekowisata. Mendorong terciptanya segmen pasar wisatawan yang menginginkan keunikan produk yang direpresentasikan oleh simbol-simbol lokal.

Pergeseran konsep kepariwisataan dunia tehadap pariwisata minat khusus atau yang dikenal dengan ekowisata di saat sekarang ini, menjadikan sebuah peluang yang tentunya sangat baik bagi Negara Indonesia yang memiliki begitu banyak potensi alam, khususnya Kabupaten Karimun Kepulauan Riau. Karimun bukan hanya memiliki potensi alam yang luar biasa bagus, namun juga posisi letak Kabupaten Karimun Kepri juga merupakan peluang besar bagi pengembangan ekowisata di Karimun.

Kabupaten Karimun Provinsi Kepulauan Riau memiliki 9 kecamatan yang terdiri dari beberapa pulau besar seperti Pulau Karimun, Pulau Kundur 
dan Pulau Sugi dan banyak pulau kecil. Pulau Karimun merupakan salah satu pulau besar yang terdapat di Kabupaten Karimun, Provinsi Kepulauan Riau (Kepri). Hampir setiap pulau di Kabupaten Karimun ini memiliki daya tarik wisata yang dapat dijadikan sumber pendapatan sekaligus sebagai lahan kerja bagi masyarakat. Pulau Karimun dan Karimun Kecil merupakan salah satu pulau yang memiliki daya tarik pariwisata yang indah serta di dukung oleh aksesibilitasnya yang tinggi. Hal ini merupakan kesempatan besar bagi Pemerintah Kabupaten Karimun untuk mengelola dan mengembangkan potensi pariwisata yang ada untuk dimanfaatkan secara optimal. Ditambah lagi dengan posisi Pulau Karimun yang berbatasan dengan Malaysia dan Singapura. Menurut data dari Badan Pusat Statistik Kabupaten Karimun Asal wisatan yang datang ke Kabupaten Karimun berasal dari berbagai Negara seperti Singapura, Malaysia, Jepang, Australia, Jerman, Belanda, Inggris, dan lain-lain.

Menurut RIPPDA (Rencana Induk Pembangunan Pariwisata Daerah) Kabupaten Karimun Tahun 2001, berdasarkan struktur PAD Karimun, sektor pariwisata menempati urutan kedua setelah pertambangan sebagai penyumbang pendapatan. Namun tidak semua DTW yang ada di Pulau Karimun dapat dikembangkan. Mengingat dalam pengembangan pariwisata dibutuhkan pembiayaan dan fasilitas yang memadai serta jumlah objek wisata yang tidak sedikit yang tersebar di Pulau Karimun. Sehingga perlu adanya pemilihan objek wisata yang memiliki keunggulan komparatif dan kompetitif yang nantinya berada dalam satu kesatuan aksesibilitas. Sehingga dapat dilakukan pengembangan dan pengelolaan pariwisata yang berkelanjutan guna meningkatkan kualitas kepariwisataan di Kabupaten Karimun Provinsi Kepri. Perkembangan dan pertumbuhan pariwisata di Pulau Karimun tentunya harus berjalan sesuai dengan potensi yang dimiliki.

Pulau Karimun Kecil yang lebih dikenal oleh penduduk dengan nama Pulau Karimun Anak merupakan sebuah pulau kecil yang berkedudukan di Desa Pongkar Kecamatan Tebing Kabupaten Karimun Provinsi Kepulauan Riau. Sejauh ini belum terdapat transportasi laut dari Tanjung Balai Karimun sebagai Ibu Kota Kabupaten untuk ke luar atapun masuk ke Pulau KarimunKecil. Untuk menuju pulau tersebut, hanya dapat ditempuh dengan 
melalui jalur laut dengan menggunakan perahu nelayan lokal yang biasa disebut pompong yang memakan waktu perjalanan kurang lebih 10-20 menit.

Kabupaten Karimun merupakan salah satu kota yang termasuk dalam zona ekonomi eksklusif (ZEE) diatur dalam undang-undang nomor 22 tahun 1999 dan undang-undang no 5 tahun 1883. Karena letaknya yang sangat strategis yang langsung berbatasan dengan dua negara sekaligus yaitu Singapura dan Malaysia jadi tidak heran apabila kabupaten karimun sangat strategis dijadiakan tempat untuk pengembangan ekonomi. Hal ini dapat dilihat dari ditetapkanya Karimun sebagai salah satu dari tiga kabupaten sebagai wilayah kawasan perdagangan bebas dan pelabuhan bebas (KPBPB atau free trade zone/FTZ). Dengan demikian lebih mempermudah bagi para turis asing untuk berkujung ke kabupaten karimun.

Kabupaten Karimun memiliki luas wilayah 7.984 km dan 6.460 km-nya adalah lautan, yang terdiri dari 198 pulau dengan 67 diantaranya berpenghuni. Karimun terdiri atas 13 Kecamatan antara lain: Belat, Bulu, Durai, Kundur Barat, Kundur Utara, Kundur, Meral Barat, Meral, Pulau Kundur, Tebing, Ungar. Dari 13 Kecamatan yang berada di Kabupaten Karimun ada salah satu kecamatan yang memiliki destinasi wisata alam terlengkap yang berada dalam satu lokasi sekaligus yaitu ada pantai sekaligus air terjun yang berada dalam satu lokasi. yaitu di kecamatan Tebing khususnya di Desa Pongkar.

Menurut data BPS Karimun yang diterbitkan pada tahun 2017, desa Pongkar memiliki luas wilayah sebesar $44,03 \mathrm{~km}^{2}$. Luas wilayah desa Pongkar memiliki rasio sekitar $63 \%$ dari luas wilayah Kecamatan Tebing saat ini. Sedangkan jarak antara desa Pongkar menuju ibukota kecamatan sekitar 11,2 km. Untuk batas-batas desa Pongkar, sebelah Utara berbatasan dengan selat Malaka, sebelah Selatan berbatasan dengan Kelurahan Pamak, sebelah Timur berbatasan dengan selat Phillip dan sebelah Barat berbatasan dengan Kecamatan Meral Barat.

Struktur masyarakat yang berada di Desa Pongkar Kabupaten Karimun terdiri dari beragam latar belakang kebudayaan meskipun masih didominasi oleh Melayu. Namun keberadaan komunitas suku laut yang merupakan bagian dari konsep Komunitas Adat Terpencil dalam Undang-undang, menjadikan wilayah Desa Pongkar menjadi lebih menarik dalam mengembangkan wisata 
berbasis kearifan lokal masyarakat setempat. Struktur kepemudaan yang berkaitan dengan pembangunan wisata di sana sudah baik, diwujudkan dalam bentuk adanya paguyuban, atau perkumpulan pemuda seluruh desa, walau terpisah dengan jarak yang cukup jauh.

Butuh adanya peleburan budaya dalam merencanakan pengembangan potensi ekowisata berbasis kearifan lokal di Desa Pongkar Kabupaten Karimun. Sehingga semua kebudayaan masyarakat di Desa Pongkar terakomodir dan tidak ada nilai-nilai masyarakatnya yang cukup beragam tersebut yang tercederai. Sehingga masyarakat Desa Pongkar tetap bisa hidup sesuai dengan nilai-nilai yang telah lama mereka jalani. Oleh sebab itu, dibutuhkan sebuah strategi yang bijak dalam mengembangkan ekowisata berbasis kearifan lokal di Desa Pongkar Kabupaten Karimun.

\section{Tinjauan Pustaka}

\section{a. Pariwisata dan Ekowisata}

Umumnya pariwisata memiliki konsep yang sangat luas, konsep ilmu kepariwisataan menurut Kusmayadi (2000) merupakan suatu kegiatan melakukan perjalanan dari rumah dengan maksud tidak melakukan usaha atau bersantai. Pariwisata di wilayah pedesaan saat ini menjadi salah satu alternative yang memiliki daya tarik tersendiri dalam kepariwisataan. Kehidupan pedesaan yang memiliki ciri khusus pada masyarakat, alam dan budayanya menjadi suatu komoditi bagi wisatawan (Hadiwijoyo, 2012).

Pembangunan pariwisata selayaknya tidaklah mengabaikan manfaat yang diterima masyarakat lokal. Masyarakat perlu diberdayakan sebagai pihak yang memiliki local knowledge, local resources dan local aaccountability. Pemberdayaan dapat dilakukan melalui penyadaran kemampuan (enabling), penguatan potensi (empowering) dan kemandirian (autonomy). Tujuannya agar masyarakat lokal dapat menjadi pelaku aktif dalam kegiatan pariwisata dan pengembangannya. Mereka juga dapat memiliki tanggung jawab moral yang tinggi dalam pemanfaatan sumberdaya yang mereka miliki, karena mereka menyadari bahwasanya keberadaan sumberdaya akan mempengaruhi kehidupan mereka (Pitana, 1999). 
Konsep kepariwisataan dunia tehadap pariwisata minat khusus atau yang dikenal dengan ekowisata mengalami pergeseran di saat sekarang ini. Hal ini merupakan sebuah peluang yang tentunya sangat baik bagi Negara Indonesia yang memiliki begitu banyak potensi alam, khususnya Kabupaten Karimun Kepulauan Riau. Karimun bukan hanya memiliki potensi alam yang luar biasa bagus, namun juga posisi letak Kabupaten Karimun Kepri juga merupakan peluang besar bagi pengembangan ekowisata di Karimun.

Secara definitif, ekowisata yang didefinisikan sebagai suatu bentuk perjalanan wisata yang bertanggung jawab ke kawasan alami yang dilakukan dengan tujuan mengkonservasi lingkungan dan melestarikan kehidupan dan kesejahteraan penduduk setempat. memperlihatkan kesatuan konsep yang terintegratif secara konseptual tentang keseimbangan antara menikmati keindahan alam dan upaya mempertahankannya. Sehingga pengertian ekowisata dapat dilihat sebagai suatu konsep pengembangan pariwisata berkelanjutan yang bertujuan untuk mendukung upaya-upaya pelestarian lingkungan (alam dan budaya) dan meningkatkan partisipasi masyarakat dalam pengelolaannya.

Ekowisata merupakan perjalanan wisata ke suatu lingkungan baik alam yang alami maupun buatan serta budaya yang ada yang bersifat informatif dan partisipatif yang bertujuan untuk menjamin kelestarian alam dan sosial-budaya. Ekowisata menitikberatkan pada tiga hal utama yaitu; keberlangsungan alam atau ekologi, memberikan manfaat ekonomi, dan secara psikologi dapat diterima dalam kehidupan sosial masyarakat. Jadi, kegiatan ekowisata secara langsung memberi akses kepada semua orang untuk melihat, mengetahui, dan menikmati pengalaman alam, intelektual dan budaya masyarakat lokal.

Secara konseptul ekowisata dapat didefinisikan sebagai suatu konsep pengembangan pariwisata berkelanjutan yang bertujuan untuk mendukung upaya-upaya pelestarian lingkungan (alam dan budaya) dan meningkatkan partisipasi masyarakat dalam pengelolaan, sehingga memberikan manfaat ekonomi kepada masyarakat setempat. Sementara ditinjau dari segi pengelolaanya, ekowisata dapat didifinisikan sebagai penyelenggaraan kegiatan wisata yang bertanggung jawab di tempat-tempat alami dan atau daerah-daerah yang dibuat berdasarkan kaidah alam dan secara ekonomi 
berkelanjutan yang mendukung upaya-upaya pelestarian lingkungan (alam dan budaya) dan meningkatnkan kesejahtraan masyarakat setempat (Dias, Satria : 2009).

Aktivitas ekowisata saat ini tengah menjadi tren yang menarik yang dilakukkan oleh para wisatawan untuk menikmati bentuk-bentuk wisata yang berbeda dari biasanya. Dalam konteks ini wisata yang dilakukkan memiliki bagian yang tidak terpisahkan dengan upaya-upaya konservasi, pemberdayaan ekonomi lokal dan mendorong respek yang lebih tinggi terhadap perbedaan kultur atau budaya. Hal inilah yang mendasari perbedaan antara konsep ekowisata dengan model wisata konvensional yang telah ada sebelumnya.

Meminimalkan dampak yang ditimbulkan terhadap lingkungan, membangun kesadaran terhadap lingkungan sekitar, menghasilkan keuntungan finansial secara langsung yang dapat digunakan untuk melakukan konservasi alam, memberikan keuntungan finansial dan memberikan kesempatan pada penduduk lokal, mempertahankan kebudayaan lokal dan tidak melanggar hak asasi manusia dan pergerakan demografi. Walaupun banyak nilai-nilai positif yang ditawarkan dalam konsep ekowisata, namun model ini masih menyisakan kritik dan persoalan terhadap pelaksanaanya. Beberapa kritikan terhadap konsep ekowisata antara lain (Dias, Satria: 2009):

1) Dampak negatif dari pariwisata terhadap kerusakan lingkungan. Meski konsep ecotourism mengedepankan isu konservasi didalamnya, namun tidak dapat dipungkiri bahwa pelanggaran terhadap hal tersebut masih saja ditemui di lapangan. Hal ini selain disebabkan karena rendahnya pengetahuan dan kesadaran masyarakat sekitar dan turis tentang konsep ekowisata, juga disebabkan karena lemahnya manajemen dan peran pemerintah dalam mendorong upaya konservasi dan tindakan yang tegas dalam mengatur masalah kerusakan lingkungan.

2) Rendahnya partisipasi masyarakat dalam Ekowisata.Dalam pengembangan wilayah Ekowisata seringkali melupakan partisipasi masyarakat sebagai stakeholder penting dalam pengembangan wilayah atau kawasan wisata. Masyarakat sekitar seringkali hanya sebagai obyek atau penonton, tanpa mampu terlibat secara aktif dalam setiap proses-proses ekonomi didalamnya. 
3) Pengelolaan yang salah. Persepsi dan pengelolaan yang salah dari konsep ekowisata seringkali terjadi dibeberapa wilayah di Indonesia. Hal ini selain disebabkan karena pemahaman yang rendah dari konsep Ekowisata juga disebabkan karena lemahnya peran dan pengawasan pemerintah untuk mengembangkan wilayah wisata secara baik.

Pengembangan ekowista bahari yang hanya terfokus pada pengembangan wilayah pantai dan lautan sudah mulai tergeser, karena banyak hal lain yang bisa dikembangkan dari wisata bahari selain pantai dan laut. Salah satunya adalah konsep ekowisata bahari yang berbasis pada pemadangan dan keunikan alam, karakteristik ekosistem, kekhasan seni budaya dan karakteristik masyarakat sebagai kekuatan dasar yang dimiliki oleh masing-masing daerah. Selanjutnya kegiatan ekowisata lain yang juga dapat dikembangkan, antara lain: berperahu, berenang, snorkling, menyelam, memancing, kegiatan olahraga pantai dan piknik menikmati atmosfer laut.

Orientasi pemanfaatan pesisir dan lautan serta berbagai elemen pendukung lingkungannya merupakan suatu bentuk perencanaan dan pengelolaan kawasan secara merupakan suatu kesatuan yang terintegrasi dan saling mendukung sebagai suatu kawasan wisata bahari. Suatu kawasan wisata yang baik dan berhasil bila secara optimal didasarkan pada empat aspek yaitu: mempertahankan kelestarian lingkungannya, meningkatkan kesejahteraan masyarakat di kawasan tersebut, menjamin kepuasan pengunjung dan meningkatkan keterpaduan serta kesatuan pembangunan masyarakat di sekitar kawasan dan zona pengembangannya.

Selain keempat aspek tersebut, ada beberapa hal yang juga perlu diperhatikan untuk pengembangan ekowisata bahari, anatara lain : Aspek Ekologis, daya dukung ekologis merupakan tingkat penggunaan maksimal suatu kawasan; Aspek Fisik, Daya dukung fisik merupakan kawasan wisata yang menunjukkan jumlah maksimum penggunaan atau kegiatan yang diakomodasikan dalam area tanpa menyebabkan kerusakan atau penurunan kualitas; Aspek Sosial, Daya dukung sosial adalah kawasan wisata yang dinyatakan sebagai batas tingkat maksimum dalam jumlah dan tingkat penggunaan dimana melampauinya akan menimbulkan penurunanan dalam tingkat kualitas pengalaman atau kepuasan; Aspek Rekreasi, Daya dukung 
reakreasi merupakan konsep pengelolaan yang menempatkan kegiatan rekreasi dalam berbagai objek yang terkait dengan kemampuan kawasan.

\section{b. Kearifan Lokal dan Partisipasi}

Di dalam kehidupan masyarakat Indonesia terdapat nilai-nilai sosial yang membentuk kearifan lokal (local wisdom) dan telah menjadi bagian dari kehidupan sehari-hari. Misalnya, gotong royong, kekeluargaan, musyawarah untuk mufakat dan toleransi. Hadirnya kearifan lokal ini tak bisa dilepaskan dari nilai-nilai religi yang dianut masyarakat Indonesia sehingga nilai-nilai kearifan lokal ini makin melekat pada diri mereka. Tidaklah mengherankan, apabila nilai-nilai kearifan lokal ini dijalankan tidak semata-mata untuk menjaga keharmonisan hubungan antar manusia, tetapi juga menjadi bentuk pengabdian manusia kepada Sang Pencipta (Suryadi, 2010).

Pengembangan wisata di wilayah pedesaan, tidak akan terlepas dari konsep partisipasi masyarkat. Masyarakat sebagai salah satu pengelola dari desa wisata sangat menjadi faktor penentu dalam pengembangan pariwisata di wilayah pedesaan. Partisipasi masyarakat dalam pengembangan wisata di pedesaan akan menjadi effektif jika pelibatannya tidak hanya sekedar di awal pengembangan atau akhir pengembangan pariwisata, melainkan masyarakat dilibatkan secara aktif dalam pengelolaan ataupun pengembangan pariwisata. Partisipasi masyarakat dalam pembangun merupakan kerjasama yang erat antara perencana dan masyarakat dalam merencanakan, melaksanakan, melestarikan dan mengembangkan hasil pembangunan yang telah dicapai.

\section{Metode Penelitian}

Metodologi adalah cara-cara yang dipakai dalam penelitian ilmiah untuk mendapatkan pengetahuan yang benar. Pengetahuan yang benar adalah kesesuaian antara pengetahuan dengan objek yang diteliti. Pengetahuan yang dimaksud di sini yakni pengetahuan yang telah dibangun dalam kajian teori, sedangkan objeknya adalah situasi sosial penelitian. Menurut Sugiyono, latar social adalah sampel dan populasi penelitian. Adapun alasan menggunakan metode kualitatif yakni ingin mendapat data secara alami (apa adanya). Penilaian akan perubahan ini menjadi salah satu sebab bagi penulis menggunakan metode kualitatif. 
Metode yang dipakai untuk mendapat data dalam penelitian ini adalah metode kualitatif maka ada komponen-komponen metode kualitatif yang harus diperhatikan oleh peneliti.

Sugiyono mengemukakan bahwa komponen-komponen penelitian yang dikenal dalam metode penelitian kualitatif yaitu. metode dan alasan menggunakan metode kualitatif, tempat penelitian, instrument penelitian, sampel sumber data penelitian, tehnik pengumpulan data, tehnik analisa data, dan pengujian keabsahan data. Penelitian ini berlokasi di Desa Pongkar, Kecamatan Tebing, Kabupaten Karimun. Di mana populasi dan sampel adalah pemerintah desa setempat beserta local community yang ada beserta dinas dan instansi-instansi terkait dengan pariwisata di Kabupaten Karimun. Dalam penelitian kuantitatif instrument penelitian itu berupa test, kuesioner, pedoman wawancara dan lain-lain. Sedangkan dalam penelitian kualitatif instrument utama dalam penelitian adalah peneliti sendiri atau anggota tim peneliti. Bagian terakhir ini dimungkinkan bila penelitian dilakukan secara tim. Jadi, instrument utama dalam penelitian ini yaitu peneliti sendiri. Selain itu peneliti juga menggunakan instrument lain seperti kuesioner dan wawancara terhadap objek yang diteliti. Ronny Kountur menyatakan: "instrument dimaksudkan sebagai alat pengumpul data. Misalnya, untuk penelitian sosial instrument penelitian berupa kuesioner, sedangkan untuk penelitian eksakta, instrument penelitian yang dipakai bermacam-macam, seperti: thermometer (alat mengukur suhu panas pada tubuh manusia), timbangan (alat pengukur berat), dan lain-lain.

\section{Pembahasan}

\section{a. Keadaan Penduduk Desa Pongkar}

Desa Pongkar adalah bagian dari kecamatan Tebing kabupaten Karimun, merupakan 1 (satu) dari 13 (tiga belas) desa atau kelurahan yang berada di kecamatan Tebing yang berbeda dengan dengan desa-desa lainya karena adanya berbagai keindahan alam yang sangat indah antara lain adanya, pantai, air terjun dan kolam pemandian dalam satu desa sekaligus. Desa Pongkar terdiri 2 (dua) dusun, 4 (empat) RW dan 11 (sebelas) RT. Dari jumlah masyarakat yang menempati desa Pongkar dapat dilihat dari julmah 
penyebaran masyarakatnya dari tahun 2012 hingga 2017, hal ini bisa kita lihat dari table berikut.

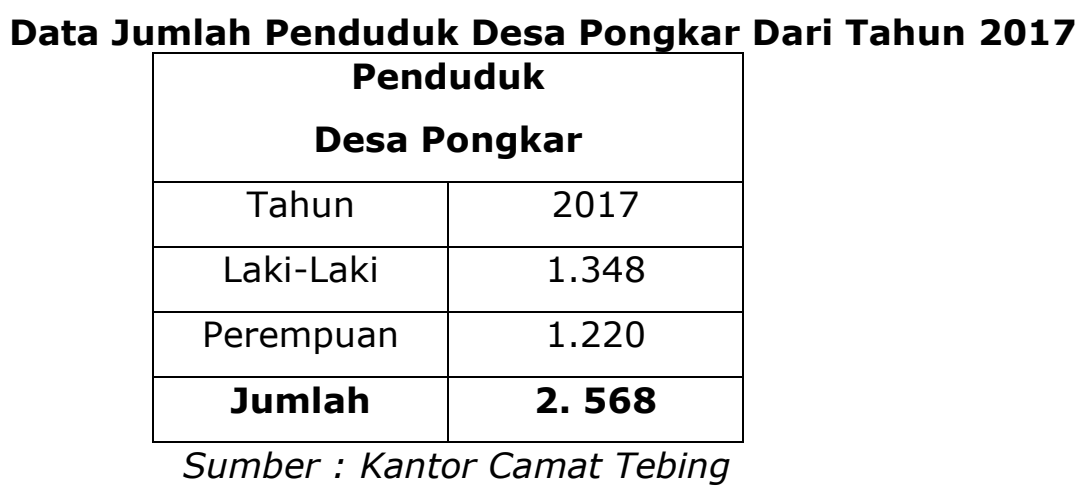

Berdasarkan dari tabel diatas dapat kita lihat bahwa penduduk desa Pongkar pada tahun 2017 berjumlah 2.568 jiwa. Secara rinci penduduk desa Pongkar yang berjenis kelamin laki-laki berjumlah 1.348 jiwa, sedangkan untuk yang berjenis kelamin perempuan berjumlah 1.220 jiwa.

\section{b. Kelembagaan Pemuda Desa Pongkar}

Desa pongkar adalah tempat dari berbagai suku yang menggambarkan keragaman yang terjalin sangat baik di masyarakat desa Pongkar. Suku-suku yang berada di dalam masyarakat desa Pongkar yaitu seperti suku Melayu, Jawa, Batak serta Bugis yang hidup berdampingan satu dengan yang lainya yang saling bantu membantu untuk mengembangkan dan mengelola pariwisata yang ada di desa Pongakar tanpa harus saling bersinggungan karena ada perbedaaan satu dengan yang lainya.

Adapun kelembagaan yang dibentuk oleh masyarak desa Pongkar yang bertujuan untuk mengembangkan pariwisata yang berada di desa. Hal ini dapat dilihat bahwa masyarakat desa pongkar memiliki kelembaggan atau stuktur masyarakat yang saling bersinergi antara pemuda dan masyarakat untuk bahu membahu membangun dan mengembangkan pariwisata setempat. Komunitas yang berada di masyarakat desa Pongkar itu sendiri bernama (karang taruna pagar alam desa Pongkar). 
204 |Dhani Akbar, Teguh SI.Peran dan Partisipasi...

\section{c. Wisata Desa Pongkar}

Kabupaten karimun terdiri dari 198 pulau dimana 67 diantaranya berpenghuni. Karena kabupaten karimun berdekatan dengan negara tetangga seperti Malaysia dan singapura hal ini menbuat banyaknya turis-turis asing masuk kekarimun. Ditambah lagi dengan banyaknya obyek wisata yang menyuguhkan pemandangan alam yang indah membuat wisatawan betah untuk terus berkunjung ke tanjung balai karimun. Salah satu obyek wisata yang banyak menyita perhatian para wisatawan adalah obyek wisata desa Pongkar yang berada di kecamatan Tebing kabupaten Tanjung Balai Karimun.

Beberapa keindahan yang disuguhkan di desa Pongkar itu sendiri adalah yaitu pantai yang menyugguhkan pemandangan yang bagus dengan adanya pulau-pulau ditengah laut yaitu pulau karimun anak dan takong hiu yang menambah keelokan pantai dan pulau-pulau tersebut dapat menahan besarnya ombak karena pantai ini merupakan bagian dari selat malaka yang terkenal akan ombanya, serta wisatawan bisa langsung bercengkrama dengan masyarakat sekitar karena tidak hanya wisatawan internasional yang berkunjung keopantai pongkar ini melainkan wisatawan lokal juga menjadikan pantai ini sebagai tembat yang faforit untuk mereka.

Seterusnya tidak jauh dari lokasi pantai pokar terdapat obyek wisata yang tak kalah menarik dengan pantai pokar yaitu air terjun pongkar. Letaknya yang berada tepat di gunung jantan, para wisatawan diajak untuk bertualan melewati perbukitan dengan berbagai keindahan alam yang masih asri sebelum tiba di spot utama yaitu air terjun pongkar. Setelah tiba di spot utama para wisatawan disuguhi air terjun yang jernih dan dingin dan ditambah pemandangan alam yang menarik serta wisatawan berendam atau hanya sejedar berfoto-foto sembari menikmati air terjun pongkar. Wisatawan merasa terbayar lunas lelahnya perjalanan menuju air terjun pongkar setelah tiba dilokasi air terjun dan merasakan sensasi air terjun dan keindahan alamnya.

\section{d. Potensi Wisata Desa Pongkar.}

Potensi wisata Kabupaten Karimun di dominasi dengan wisata Bahari, Salah satu wisata bahari dengan panorama pasir putih yang membentang luas di sepanjang bibir pantai. Memiliki potensi wisata bahari yang berbeda 
dari lainnya adalah pantai Pongkar. Salah satu bentuk perbedaan pantai pongkar dengan pantai-pantai yang lain adalah adanya Pohon-pohon cemara yang berbaris di sepanjang tepi pantai dan memiliki panorama yang indah dengan pemandangan pengunungan Karimun serta akan melihat betapa pesonanya Pulau Karimun anak.

Keberadaan Pantai Pongkar memiliki daya tarik tersendiri dengan hamparan pasir putih yang membentang disepanjang bibir pantai serta mempunyai suasana lautan yang luas nan biru membuat masyarakat berbondong-bondong menghabiskan liburannya di pantai ini. Karena pantai Pongkar merupakan wisata bahari yang paling diminati oleh masyarakat Karimun maupun wisatawan luar karimun, setiap hari bahkan setiap liburan Pengunjung terus berdatangan untuk mengunjungi indahnya Panorama Pantai Pongkar. Tidak hanya pantai terkenal dengan pantainya namun ada lokasi yang dijadikan icon baru dari desa pongkar yaitu Kolam Renang yang airnya bersumber langsung dari pegununggan sepempat yang pastinya menyejukan badan dan bersih.

Dipantai Pongkar Juga tidak kalahnya dengan pantai-pantai yang lainya, pengunjung juga bisa olah aga jantung dengan menyewa Banana Boat seharga Rp. 20.000,- perorang, namun banyak pengunjung yang mengantri untuk melihat eksotis pemandangan pantai pongkar serta melihat Gununggunung dari jarak jauh kelihatan berwarna biru tua yang berada di sisi kiri dan kanan pantai sehingga jika wisatawan beristirahat di pantai merasa tidak bosan. Tidak Perlu kawatir akan difasilitasi keamanan yang dilengkapi dengan pengaman yang super ketat dan jika tidak bisa berenang akan di berikan baju pelampung serta akan diawasi full oleh pemandu banana boat,. Bahkan, di kawasan pantai juga bisa diciptakan tempat-tempat pemancingan ikan dan menyelam (diving) di air lautnya.

Dari Pantai Pongkar, wisatawan juga bisa mengunjungi obyek wisata air terjun yang letaknya sekitar dua kilometer ke arah tenggara yang masih dalam satu desa yang sama yaitu desa Pongkar. Menuju air terjun, wisatawan bisa menikmati keindahan alam dan hutan. Apalagi letak air terjun berada di perbukitan sekitar 700 meter dari ketinggiannya, dengan demikian wisatawan dapat menikmati pemandangan alam yang masih asri dengan rindangnya pepohonan dan suara kicauan burung. Ditambah lagi infrastruktur 
206 |Dhani Akbar, Teguh SI.Peran dan Partisipasi...

jalan menuju lokasi sudah tersedia dengan lebar badan jalan sekitar enam meter sehingga bisa dilalui dengan dua lajur kendaraan roda dua dan empat.

\section{e. Partisipasi Pemuda dalam Gerakan Sadar Wisata.}

Industri kepariwisataan memiliki potensi menghasilkan devisa yang sangat besar. Menurut beberapa ahli, dewasa ini industri kepariwisataan sudah menjadi bidang usaha terbesar ketiga setelah minyak dan perdagangan senjata. Ada sebagian ahli yang menyatakan bahwa, kepariwisataan merupakan bidang usaha terbesar setelah minyak. Pengembangan kepariwisataan juga merangsang tumbuhnya usaha-usaha ekonomi tertentu yang saling merangkai dan saling menunjang, misalnya jika wisatawan membeli kerajinan atau cindera mata yang dijajakan di tempat wisata secara otomatis para pengrajin memerlukan bahan baku untuk membuat barangbarang kerajinan tersebut (Munawaroh, dkk, 1999).

Industri kepariwisataan juga tidak terlepas dari peran SDM (Sumber daya manusia) khususnya pemuda. Seperti yang telah dicantumkan dalam Undang-Undang No 40 Tahun 2009 tentang Kepemudaan pasal 1 menyebutkan definisi pemuda adalah warga negara Indonesia yang memasuki periode penting pertumbuhan dan perkembangan yang berusia 16 (enam belas) sampai 30 (tiga puluh) tahun. Pemuda merupakan tonggak terpenting dalam mewujudkan kemajuan bangsa lewat pemikiran-pemikiran mereka yang kreatif. Oleh karena itu negara lewat UU no.40 Tahun 2009 pasal 5, yang Menjelaskan pelayanan kepemudaan berfungsi melaksanakan penyadaran, pemberdayaan, dan pengembangan potensi kepemimpinan, kewirausahaan, serta kepeloporan pemuda dalam segala aspek kehidupan bermasyarakat, berbangsa, dan bernegara. Maka dibutuhkan wadah untuk menampung segala bentuk ide-ide maupun pemikiran kreatif para pemuda tersebut, salah satu contohnya adalah Karang Taruna.

Kehadiran Karang Taruna sangat penting dalam pembangunan dan pengembangan desanya. Meskipun tidak semua kelompok Karang Taruna berperan aktif, paling tidak tenaga dan pikiran mereka sangat dibutuhkan dalam setiap pembangunan desa. Saat ini banyak desa-desa di Indonesia khususnya Provinsi Kepulauan Riau yang diberikan mandat sebagai desa sadar wisata dikarenakan banyaknya potensi-potensi yang dimiliki serta juga 
sebagai bentuk tanggung jawab sebuah desa untuk bisa mengelola keberadaan potensi-potensi wisata tersebut sebagai sumber income untuk masyarakatnya. Demi mensukseskan program sadar wisata tersebut, dibutuhkan sinergitas yang baik antara masyarakat dan perangkat desa sehingga timbul kesadaran untuk memajukan perekonomian desa via program sadar wisata ini.

Partisipasi pemuda dalam program sadar wisata seharusnya memang digalakkan sebagai sebuah pembelajaran bagi para pemuda bahwa mereka juga punya peran dan tanggung jawab dalam memajukan desanya. Hal ini juga yang sedang dilaksanakan oleh desa Pongkar, yang berada di Kecamatan Tebing, Kabupaten Karimun, Provinsi Kepulauan Riau. Partisipasi para pemuda di desa Pongkar bisa dikatakan cukup baik, namun alangkah baiknya tidak saja berperan dalam partisipasi tapi juga ikut ambil bagian dalam pengembangan desa tersebut karena bisa saja timbul banyak pemikiranpemikiran yang lebih segar. Oleh karena itu, bimbingan dari para perangkat desa dirasakan sangat penting agar para pemuda setempat lebih berani untuk show up di lingkungan masyarakat.

Peran pemuda dalam Gerakan Sadar Wisata diwujudkan dalam kegiatan pengembangan wisata, dari hulu hingga ke hilir, yaitu dari pengusulan kawasan wisata baru dari kelompok pemuda, hingga hasilnya diusulkan ke Desa dan Dinas Pariwisata Kabupaten Karimun.

\section{f. Partisipasi Pemuda dalam Pengelolaan Wisata.}

Partisipasi berasal dari bahasa Inggris yaitu "participation" yang bermakna pengambilan bagian atau pengikutsertaan. Secara sederhana diartikan bahwa partisipasi merupakan suatu gejala demokrasi dimana orang diikutsertakan dalam sebuah perencanaan serta dalam pelaksanaan dan juga ikut memikul tanggung jawab sesuai dengan tingkat kematangan dan tingkat kewajibannya. Partisipasi itu menjadi baik dalam bidang-bidang fisik maupun bidang mental serta penentuan kebijaksanaan. Bentuk partisipasi yang nyata yaitu:

- Partisipasi Uang

- Partisipasi Harta Benda

- Partisipasi Tenaga

- Partisipasi Keterampilan 
- Partisipasi Buah Pikiran / Ide

Bila merunut pada penjelasan mengenai partisipasi tersebut, maka banyak ragam partisipasi yang mampu dilakukan oleh individu-individu dalam sebuah masyarakat. Begitu pula halnya dengan para pemuda desa Pongkar, sedikit banyak mereka telah ikut berpartisipasi dalam program sadar wisata tersebut. Kesadaran para pemuda lewat Karang Taruna desa Pongkar ini patut diapreasiasi karena pada masa ini banyak pemuda yang lebih fokus pada kesenangan pribadi dan menghabiskan waktu untuk kegiatan-kegiatan yang tidak bermanfaat.

Dari informasi yang didapat, bahwa partisipasi pemuda Karang Taruna desa Pongkar masih sebatas pada partisipasi tenaga. Kehadiran pemuda Karang Taruna tidak lebih dari sekedar ikut membantu apabila perangkat desa meminta bantuan mereka dalam menjaga maupun mengerjakan apaapa yang dibutuhkan sesuai dengan instruksi Kepala desa. Paling tidak, para pemuda Karang Taruna tersebut diberikan tanggung jawab dalam menjaga aset desanya tersebut. Ini merupakan langkah positif pemerintah setempat dalam mengikutsertakan pemuda sebagai salah satu bagian dalam menciptakan desa Pongkar sebagai desa Sadar Wisata.

Dari pernyataan para ahli, penulis dapat memberikan kesimpulan bahwa pariwisata merupakan suatu perjalanan yang dilakukan oleh seseorang maupun sekelompok orang ke tempat tertentu yang memiliki potensi-potensi pariwisata dengan tujuan untuk mencari suatu kebahagiaan dengan lingkungan hidup dalam jangka waktu sementara, dan kegiatan ini pun nantinya akan meningkatkan pertumbuhan ekonomi suatu negara karena secara tidak langsung kegiatan ini akan memberikan peluang bagi seseorang atau masyarakat untuk memperoleh suatu pekerjaan, dan hal ini pun tentu akan mempercepat laju pertumbuhan ekonomi suatu negara.

Pariwisata memiliki peran yang sangat penting bagi kemajuan wilayah setempat maupun bagi perekonomian negara secara keseluruhan. Karena pada hakikatnya pariwisata adalah salah satu sektor andalan pemerintah Indonesia untuk menghasilkan devisa negara, sehingga pemanfaatan, pengembangan, pengelolaan, dan pembiayaan kawasan wisata harus mendapat perhatian yang serius dari pemerintah dengan melibatkan peran 
lembaga-lembaga pemerintah, serta seluruh lapisan masyarakat. Pemuda menjadi salah satu bagian penting dalam setiap pembangunan, karena pemuda dalam sejarahnya selalu bisa menciptakan sesuatu yang baru dan suatu kalangan yang mampu menggebrak pergerakan sejarah.

Dalam melaksanakan kegiatan pembangunan baik itu pembangunan fisik maupun non fisik sangat diperlukan partisipasi masyarakat, terlebih lagi pemuda sebagai bagian masyarakat yang menjadi tumpuan dalam melakasanakan kegiatan pembangunan karena pembangunan nasional menjadi kurang berhasil atau tidak berhasil hanya jika sebagian pemuda tidak berpartisipasi atau kurang berpartisipasi dalam pembangunan. Menurut Slamet "Partisipasi pemuda dalam pembangunan dapat diartikan sebagai ikut sertanya pemuda dalam pembangunan ikut serta dalam pembangunan dan ikut serta memanfaatkan dan menikmati hasil-hasil pembangunan (Slamet, 1984).

Dalam pembangunan desa sadar wisata Pongkar, keberadaan pemuda lewat Karang Taruna memang punya andil meskipun perannya belumlah dikatakan sangat berpengaruh. Meskipun ikut terjun dalam pengelolaan desa wisata, alangkah baiknya Karang Taruna tersebut diberi tanggung jawab besar lewat partisipasi dalam mengembangkan desa sadar wisata sehingga para pemuda tersebut mengerti akan tata cara kelola desa wisata yang teroganisir dengan baik. Namun, kepala desa Pongkar belum mengikutkan pemuda tersebut dalam pengembangan desa wisata sehingga hal ini masih dalam ranah pengurusan desa. Seharusnya pemerintah desa mampu memberikan ruang kepada para pemuda Karang Taruna untuk lebih bisa menampilkan ide-ide maupun gagasannya, agar para pemuda ini juga merasa bahwa suaranya ikut didengar pemerintah desa setempat. Pemerintah desa seharusnya memberikan kepercayaan yang besar kepada para pemuda bahwa mereka juga mampu untuk ikut dalam mengembangkan kemampuan desa wisatanya. Lewat bimbingan yang dilakukan oleh aparatur desa dan para ahli yang mahir di bidangnya sehingga ketika para pemuda ini sudah dikatakan layak dan mampu, maka mereka bisa dilepaskan untuk mengurusi desa wisata Pongkar tersebut dengan pemerintah desa sebagai pengawas. 
210 |Dhani Akbar, Teguh SI.Peran dan Partisipasi...

\section{Kesimpulan Dan Saran}

Keikutsertaan pemuda karang taruna desa Pongkar kecamatan Tebing hanya sebatas dalam pengelolaan dan perawatan wisata. Dengan minimnya peran yang diberikan kepada pemuda desa Pongkar, maka gagasan maupun ide-ide yang seharusnya hadir dari para pemuda tersebut juga jadi tidak mampu direalisasikan secara baik. Potensi wisata yang berada di desa Pongkar terdiri atas 3 (tiga) ragam potensi yaitu terdiri dari pantai pongkar, air terjun pongkar dan kolam renang. Pengembangan potensi wisata desa Pongkar perlu andanya kerja sama atar beberapa pihak seperti Akedemisi, Pemerintah, Masyarakat serta pihak Swasta utuk menjadikan desa Pongkar sebagai lokasi pariwisata ternama di Kecamatan Tebing, Kabupaten Karimun.

\section{Saran}

1. Demi mensukseskan program sadar wisata, dibutuhkan sinergitas yang baik antara masyarakat kususnya para pemuda dan perangkat desa sehingga timbul kesadaran untuk memajukan perekonomian desa via program sadar wisata ini.

2. Pemerintah desa seharusnya memberikan kepercayaan yang besar kepada para pemuda bahwa mereka juga mampu untuk ikut dalam mengembangkan kemampuan desa wisatanya. Lewat bimbingan yang dilakukan oleh aparatur desa dan para ahli yang mahir di bidangnya sehingga ketika para pemuda ini sudah dikatakan layak dan mampu, maka mereka bisa dilepaskan untuk mengurusi desa wisata Pongkar tersebut dengan pemerintah desa sebagai pengawas.

\section{DAFTAR PUSTAKA}

Hadiwijoyo, perencanaan pariwisata berbasis masyarakat (sebuah pendekatan konsep). Graha ilmu : Yogyakarta

Hadiwijoyo, perencanaan pariwisata berbasis masyarakat (sebuah pendekatan konsep). Graha ilmu : Yogyakarta

Kusmayadi dan Endar S, metodologi penelitian dalam bidang pariwisata. Pt gramedia pustaka utama : Jakarta 
Kusmayadi dan Endar S, metodologi penelitian dalam bidang pariwisata. Pt gramedia pustaka utama : jakarta

Pitana, I Gede. Community management dalam pembangunan pariwisata, analisis pariwisata. Vol. 2 no. 2

Pitana, I Gede. Community management dalam pembangunan pariwisata, analisis pariwisata. Vol. 2 no. 2

Suryadi, dede. Berawal dari kearifan lokal. www.edesuryadi.com. 